\title{
"Anosmia" the mysterious collateral damage of COVID-19
}

\author{
Abdulrahman K. Ahmed ${ }^{1}$ - Reem Sayad ${ }^{1}$. Islam A. Mahmoud ${ }^{1}$ - Aya M. Abd EL-Monem ${ }^{1} \cdot$ Salma H. Badry ${ }^{1}$. \\ Islam H. Ibrahim ${ }^{1}$. Mahmoud HR Hafez ${ }^{2} \cdot$ Mohamed A. El-Mokhtar $^{3,4} \cdot$ Ibrahim M. Sayed $^{3}$ (D)
}

Received: 7 June 2021 / Revised: 1 October 2021 / Accepted: 1 February 2022 / Published online: 5 March 2022

(c) Journal of NeuroVirology, Inc. 2022

\begin{abstract}
COVID-19 pandemic spreads worldwide, with more than 100 million positive cases and more than 2 million deaths. From the beginning of the COVID-19 pandemic, several otolaryngologists described many cases of a sudden loss of smell (anosmia) associated with the disease with or without additional symptoms. Anosmia is often the first and sometimes the only sign in the asymptomatic carriers of COVID-19. Still, this disorder is underestimated, and it is not life-threatening. However, it significantly decreases the quality of life. This olfactory dysfunction continues in several cases even after the nasopharyngeal swab was negative. The occurrence of anosmia can be used as a screening tool for COVID-19 patients and can be used to identify these patients to accomplish the isolation and tracking procedures. In this review, we highlighted the possible mechanisms of anosmia in COVID-19 patients, major pathologies and features of anosmia, implications of anosmia in early diagnosis of COVID-19, evaluation of the smell function during COVID-19, and management and treatment options of COVID-19 anosmia.
\end{abstract}

Keywords COVID-19 $\cdot$ Anosmia $\cdot$ Mechanisms $\cdot$ Implications $\cdot$ Features $\cdot$ Diagnosis

\section{Introduction}

COVID-19 is caused by SARS-CoV-2, which is a new strain of the coronavirus. The pandemic had emerged in Wuhan, China, and spread rapidly throughout China and successively worldwide (Huang et al. 2020; Zhu et al. 2020). Many studies from the USA, Asia (China, South Korea, Iran), Europe (France, Spain, Italy, UK, Germany), and Australia have revealed various levels of smell loss (anosmia/hyposmia/ dysosmia) as an early symptom of COVID-19 (Abalo-Lojo et al. 2020; Aggarwal et al. 2020; Gautier and Ravussin

Mohamed A. El-Mokhtar

elmokhtarma@aun.edu.eg

$\triangle$ Ibrahim M. Sayed

Ibrahim.ibrahim@aun.edu.eg;

Ibrahim.ibrahim1@med.au.edu.eg

1 Faculty of Medicine, Assiut University, Assiut, Egypt

2 International Scholar, African Leadership Academy, 1050 Printech Road, Laser Park, Honeydew, Johannesburg, South Africa

3 Department of Medical Microbiology and Immunology, Faculty of Medicine, Assiut University, Assiut, Egypt

4 Microbiology and Immunology Department, Faculty of Pharmacy, Sphinx University, Assiut, Egypt
2020; Gilani et al. 2020; Hopkins et al. 2020; Huang et al. 2020, Merza et al. 2020). It was found that sudden anosmia in asymptomatic infected patients could be the early and only symptom of the disease. Self-isolation should be started before alerting the health authorities to patients who acquired anosmia (Roland et al. 2020; Yan et al. 2020).

COVID-19-related anosmia is often not associated with nasal obstruction (Huart et al. 2020; Lechien et al. 2020a, b, c; Altundag et al. 2021). In some studies, the incidence of anosmia has been observed up to $>80 \%$ of COVID-19 patients; $11.8-35.5 \%$ of patients may have anosmia without any other clinical symptoms (Beltrán-Corbellini et al. 2020; Lechien et al. 2020a, b, c). A unique feature of the COVID19 anosmia is its transient course, which begins suddenly regardless of other features and improves gradually over a short period (about 2 weeks) (Lechien et al. 2020a, b, c). Other studies have supported the spontaneous improvement of anosmia with a mean duration of 2-3 weeks (Heidari et al. 2020; Hornuss et al. 2020). However, patients with more than 1 month of anosmia, known as persistent anosmia, have also been observed (Kandemirli et al. 2021; Tsivgoulis et al. 2021). Taking into consideration that olfactory epithelium undergoes regeneration over $6-8$ weeks, COVID-19 could lead to anosmia of more than 2-3 weeks up to 6-8 weeks due to epithelial damage (Altundag et al. 2021). 


\section{Anatomy and physiology of smell sensation}

The olfactory epithelium, which is responsible for olfaction, is present in the upper part of each side of the nasal cavity. It overlies the superior turbinate, the roof, and the upper part of the nasal septum. The olfactory epithelium is also present in the anterolateral part of the middle turbinate and the posterior part of the nasal septum (Kern 2000). The olfactory epithelium consists of five main types of cells, namely, sustentacular cells, the olfactory sensory neurons (OSNs), duct cells of Bowman's glands, basal cells, and microvillar cells (van Riel et al. 2015). The olfactory sensory neurons are bipolar cells projecting their dendritic processes externally into the nasal cavity (Liang 2018), and these dendritic processes present the olfactory receptors (ORs) are G-protein coupled receptors (Brennan 2018).

The odorants, either inhaled through the nose or entered through the mouth, reach the olfactory epithelium, and bind to the olfactory receptors resulted in the formation of cyclic adenosine monophosphate (cAMP) and chloride ions efflux (Kern 2000; Attems et al. 2015). The action potential is then transmitted through the olfactory sensory neurons (OSNs) axons to the olfactory bulb on the ventral surface of the frontal lobe. After that, the signals are transmitted from second-order neurons (axons of mitral and tufted cells) to the olfactory areas in the anterior part of the temporal lobe (anterior olfactory nucleus), the olfactory tubercle, and the amygdala (Attems et al. 2015; Diodato et al. 2016). Some fibers in the hippocampus cause memory and emotional response associated with smell sensation (Aqrabawi and Kim 2020).

\section{Mechanisms of anosmia associated with COVID-19 infection}

Since anosmia is an early and occasionally the only symptom of COVID-19 infection, researchers have proposed five possible mechanisms for the pathogenesis of anosmia associated with COVID-19 (Fig. 1). (1) Affection of AngiotensinConverting Enzyme 2 Receptors "ACE2," (2) damage of

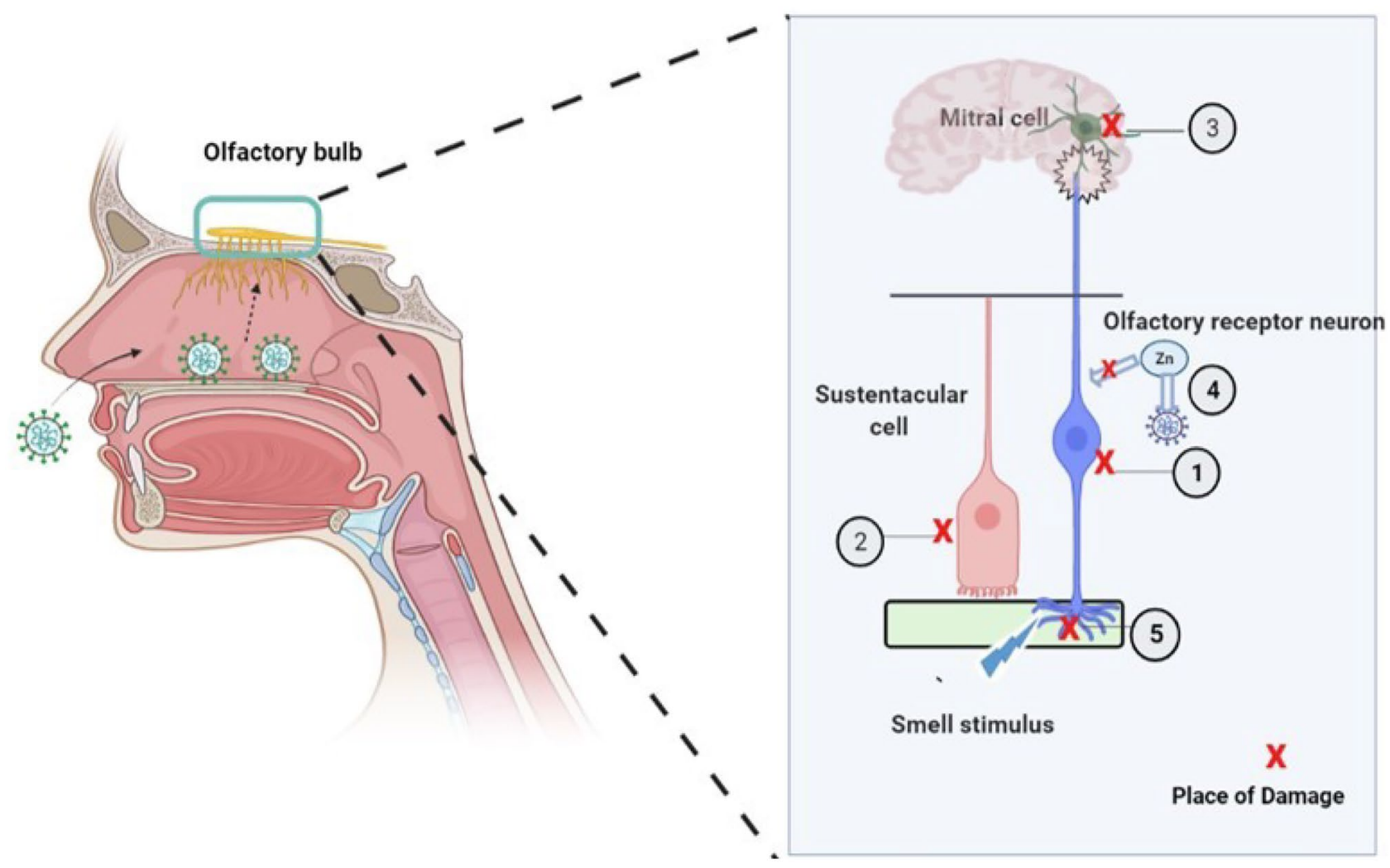

Fig. 1 General scheme of the five possible mechanisms that illustrate how the SARS-Cov-2 virus may cause anosmia (adapted from Butowt and Bartheld 2021). (1) SARS-Cov2 causes a damage of ORN; (2) the virus causes a damage of sustentacular cells; (3) damage of the mitral cell in the olfactory bulb of the brain may also comprise the transmission of odor sensation. (4) Utilization of $\mathrm{Zn}$ by the virus prevents its utilization by carbonic anhydrase which is a critical enzyme to maintain the smell function. (5) Following the infection, nasal obstruction caused by increased mucous may prevent the smell stimulus from reaching ORN 
supporting cells of the olfactory epithelium, (3) affection of frontal lobe (olfactory centers), (4) inflammatory obstruction of olfactory clefts, and (5) effect of zinc deficiency.

\section{Affection of Angiotensin-Converting Enzyme 2 Receptors "ACE2"}

Although the exact mechanism has not been established, yet some studies-performed on either human specimen from different tissues or on animal models such as micesuggest that the entry of the SARS-CoV-2 virus into the cells depends on the expression of ACE2 and Transmembrane protease serine 2 (TMPRSS2) by the target cells (Hamming et al. 2004; Sungnak et al. 2020). By analysis 15 different organs collected from 93 patients' biopsies, Hamming and colleagues showed that ACE2 is profusely present in human organs, especially in the epithelial of lung and small intestine suggesting that these places are targets of entry for the SARS-CoV (Hamming et al. 2004). Moreover, ACE2 is expressed in human vascular endothelium explaining the pathogenesis of the SARS-CoV (Hamming et al. 2004). Using C57BL/6J mouse model, Bilinska et al. reported that ACE2 and TMPRSS2 are expressed in murine sustentacular cells of the olfactory epithelium which are the target of SARSCoV-2 entry and anosmia (Bilinska et al. 2020). Sungnak and colleagues assessed the transcript expression of genes involved in the viral entry in healthy human donors using single-cell RNA sequencing, and they showed that ACE2 and TMPRSS2 genes are highly expressed in respiratory, intestinal, and corneal epithelial cells, together with innate immunity genes, suggesting the role of the previous genes in SARS-COV transmission and clearance (Sungnak et al. 2020).

SARS-CoV-2 virus utilizes these receptors for entry without inducing a local inflammatory response; therefore, more than $50 \%$ of the infected patients have smell dysfunction despite the absence of nasal congestion or rhinorrhea (Kaye et al. 2020; Lechien et al. 2020a, b, c). Many cells express ACE2 throughout the body such as olfactory epithelium (Brann et al. 2020), ciliated and goblet cells of respiratory epithelium, oral mucosa, salivary glands, epithelium of the tongue including taste buds (Chen et al. 2020a) which can explain the occurrence of both anosmia and ageusia concurrently; although each one of them may occur separately. SARS-CoV-2 virus is suggested to cause anosmia by binding to ACE2 receptors on OSNs, sustentacular cells, and Bowman's glands leading to functional damage and disruption (Cooper et al. 2020; Li et al. 2020a, b). Importantly, the expression of these receptors is low in the olfactory sensory neurons, so another suggested possibility is through infection of sustentacular cells and Bowman's glands which showed higher expression of these entry proteins than the OSNs; damage of these cells may cause disruption of the function of OSNs.

\section{Damage of supporting cells of the olfactory epithelium}

Sustentacular cells are supporting cells for the olfactory neurons, and they are supplying the neuronal cells with nutrients, getting rid of residual odorant-binding proteins, and maintaining the structural integrity of the olfactory epithelium (Heydel et al. 2013; Cooper et al. 2020). SARS-CoV-2 virus is present mostly in the sustentacular cells and pericytes due to the abundance of ACE2 and TMPRSS2 where the damage of these cells was done both metabolically and functionally leading to smell abnormalities up to complete loss of smell sensation (Bryche et al. 2020; Meinhardt et al. 2021).

Bertrand Bryche et al. showed the effect of SARS-CoV-2 infection on the olfactory system in golden Syrian hamsters using confocal double-label immunostaining and revealed that there was great damage to a large number of sustentacular cells and a major loss of cilia necessary for odor detection.

Anosmia and hyposmia caused by SARS-CoV-2 are caused by either direct effect of the virus on the sustentacular cells leading to functional disturbance or indirect effect on olfactory sensory neurons leading to metabolic and functional disturbance (Heydel et al. 2013). Another possible mechanism of anosmia is the inflammatory response released against the virus including the release of proinflammatory cytokines such as tumor necrosis factor-alpha (TNF- $\alpha$ ) leading to damage of the olfactory epithelium which results in dysfunction of the sensory odorant neurons (Bryche et al. 2020; Meinhardt et al. 2021).

The regeneration of damaged olfactory sensory neurons usually takes from 8 to 10 days followed by another 5 days for the maturation of their dendritic processes (Schwob et al. 1995; Schwob 2002; Brann and Firestein 2014; Liang 2018), which is longer than the recovery period of the smell dysfunction associated with SARS-CoV-2 that usually resolve or markedly improve in about one week (Lechien et al. 2020a, b, c; von Bartheld et al. 2020), while damaged sustentacular cells require a shorter time to regenerate (Schwob et al. 1995; Schwob 2002) which is more consistent with the duration of COVID-19 anosmia.

\section{Affection of the frontal lobe (olfactory centers)}

Although it is obvious that the respiratory tract is the most important site of infection, the brain has been shown to be affected by the virus or viral products. Lambrecq et al. (2021) reported frontal EEG changes in 24 cases out of 35 positive COVID-19 patients (Lambrecq et al. 2021). Large cohort studies concluded that delirium and frontaltype behavioral changes were often described in COVID19 patient (Helms et al. 2020). SARS-CoV-2 virus invades 
the central nervous by binding to ACE2 receptor; however, the exact pathophysiology of SARS-CoV-2 neuro-invasiveness in different brain tissues during infection is still not completely understood ( $\mathrm{Li}$ et al. 2020a, b). The expanded neurological manifestations associated with the infection led some researchers to believe that SARS-CoV-2 is neurotropic (Butowt and Bilinska 2020; Gomez-Pinedo et al. 2020; Paniz-Mondolfi et al. 2020; Politi et al. 2020). However, there is currently a lack of precise experimental proof of SARS-CoV-2 neuroinvasiveness in various brain tissues. In fact, it is still unknown if and how SARS-CoV-2 infects distinct parts of the brain after crossing the blood-brain barrier (Zhang et al. 2021).

In postmortem study of positive COVID-19 patients died in the hospitals in Germany, it was reported that SARSCoV-2 was detected in the brain of 53\% (21/40) of examined patients, though there was no clear evidence that SARSCoV-2 damages the CNS (Matschke et al. 2020). Postmortem study of a 74-year-old male infected with SARS-CoV-2 in China reported the presence of SARS-CoV-2 in the frontal lobe tissues in the neural and capillary endothelial cells (Paniz-Mondolfi et al. 2020). In Italy, autopsy of a male 54-year patient showed severe tissue damage, involving the olfactory nerve, the gyrus rectus, and the brain stem with detectable virus in the tissues (Bulfamante et al. 2020). In addition, analysis of human transcriptome databases showed that ACE2 receptor is strongly expressed on many brain locations, including the olfactory bulb, the pericytes, and endothelial cells supporting the permissiveness of the CNS to SARS-CoV-2 infection (Chen et al. 2020b). Sustentacular cells of the olfactory epithelium are primary supporting cells for the epithelium and important for the metabolism of olfactory neurons and odor perception; therefore, the damage induced by SARS-CoV-2 in these cells may contribute to the olfactory impairments in COVID-19 patients (Bilinska et al. 2020). Interestingly, the previous variant of coronavirus, SARS-CoV-1, that first emerged in China in 2002, could infect the olfactory neurons of mice transgenic for human ACE2. The initial infection was followed by rapid transneuronal transport of the virus to different areas of brain and was associated with death of the animal (Netland et al. 2008).

On the other hand, other studies on human, hamster, and mice reported that the SARS-COV2 does not/ or less infect the olfactory receptor neurons (Bilinska et al. 2020; Brann et al. 2020; Bryche et al. 2020; Bilinska et al. 2021). The discrepancies in reports of the ability of the virus to infection the neurons may be attributed to the difference in the methods used to describe the expression of the receptor. Majority of the reports did not provide accurate quantitative analyses of the receptor expression. In addition, it is possible to get false positive results from immune fluorescence images of an infected sustentacular cell that phagocytosed a neuron or its debris. These cells which contain the viral protein colocalized with a neuronal marker. Moreover, studies-based detection of the spike protein in the brain may provide false positive results result from the shed spike protein without containing the virus (reviewed by Butowt et al. (2021)).

\section{Inflammatory obstruction of olfactory clefts}

Most COVID-19 patients suffer from obstruction of olfactory clefts totally which causes olfactory dysfunction (Eliezer et al. 2020), but the exact cause of olfactory clefts obstruction remains unknown (Trotier et al. 2007). Laurendon et al. found olfactory clefts accompanied by mild edema and olfactory bulbs in both sides in MRI of COVID19 patient (Laurendon et al. 2020). The interaction between SARS-CoV-2 and ACE2 may be the cause of this edema that could be one of the causes of anosmia.

\section{Effect of zinc deficiency}

Zinc ( $\mathrm{Zn})$ is an essential nutrient in the human body. It is needed for cell growth, differentiation, and survival (Andreini et al. 2006). Also, $\mathrm{Zn}$ acts as a cofactor for proteins through catalytic functions of enzymes and transcription factors and acting as a second messenger (Fukada and Kambe 2018). Zinc deficiency is a predisposing factor of COVID-19 because its deficiency causes thymic atrophy and depression in both adaptive and innate immune responses which increase the susceptibility to infection (Shankar and Prasad 1998). SARS-CoV-2 virus causes $Z n$ deficiency after infection through the utilization of cellular $\mathrm{Zn}$ for viral replication and chelation (Wessels et al. 2020). The level of $\mathrm{Zn}$ is decreased to in $60 \%$ of patients with a viral infection, and stayed low for several weeks (Srinivas et al. 1988). $\mathrm{Zn}$ deficiency is a common cause of anosmia because of the decrease in the function of zinc-dependent metalloenzyme called carbonic anhydrase (CA) which is a critical enzyme to maintain the smell function (Komai et al. 2000). Hence, $\mathrm{Zn}$ level is correlated to COVID-19 anosmia.

\section{The implication of anosmia in early diagnosis of COVID-19}

Anosmia is an early and sometimes the only symptom of COVID-19, which could be a beneficial tool for early detection and prevention of further spread of the pandemic for the following reasons:

- The high prevalence of anosmia in COVID-19 patients. A multicenter case series that was conducted on 1420 European COVID-19 cases (laboratory-diagnosed with RT-PCR), using a standardized questionnaire, showed 
that 997 cases $(70.2 \%)$ reported smell loss (Lechien et al. 2020a, b, c). Another multicenter European study, that used certain questionnaires based on the smell and taste component of the National Health and Nutrition Examination Survey and the short version of the Questionnaire of Olfactory Disorders-Negative Statements (sQOD-NS), showed that out of 417 laboratory-confirmed COVID19 cases with RT-PCR, 357 cases $(85.6 \%$ ) had olfactory dysfunction, among them, there was 284 (79.6\%) having anosmia (Lechien et al. 2020a, b, c).

- Anosmia can be the earliest symptom of COVID-19 (Lechien et al. 2020a, b, c; Vaira et al. 2020a, b). The prospective multicenter cohort study done on 55 French patients mainly complaining of loss dysfunction with 51 of them were COVID-19 positive based on RT-PCR; olfactory dysfunction revealed that the impairment of the smell sensation was the first symptom in 16 (29.1\%) of the patients (Salmon Ceron et al. 2020).

- Anosmia as a symptom of COVID-19 can be of sudden onset, spontaneous recovery, and a variable duration (it may last below or more than 5 days with a maximum of 2 weeks in some cases, but it can last even more than this period in other patients). Anosmia was also reported without any association of nasal obstruction or rhinorrhea in a considerable proportion of COVID-19 cases (Lechien et al. 2020a, b, c). In an aforementioned study, made on 55 patients in France, there were 47 (88.7\%) out of 53 of them complained of a sudden onset of smell affection (Salmon Ceron et al. 2020). Besides this, in a study performed in Italy on 53 COVID-19 cases who experienced chemo-perceptive affection, 35 (66\%) of them reported spontaneous complete recovery of their chemosensory dysfunction; nonetheless, by using the Connecticut Chemosensory Clinical Research Center olfaction test and another standardized test for taste, the results asserted that there were still $80 \%$ of these patients with some levels of chemosensory diminution (Vaira et al. 2020a, b). In addition, it was reported by an abovementioned study (of 1420 cases) that of those with smell loss (997 cases), there were $29.4 \%$ without nasal obstruction and $38.5 \%$ without rhinorrhea (Lechien et al. 2020a, b, c).

- Smell affection due to COVID-19 is very common in young patients who spend a lot of their time outdoors leading to more spread of the disease (Lechien et al. 2020a, b, c; Salmon Ceron et al. 2020).

All these reasons encourage using smell tests as a screening tool for COVID-19. In spite of the predicted low specificity of these tests, as anosmia is a common symptom of the abovementioned diseases and it can be caused by some of the drugs used for COVID-19 treatment, their predicted high sensitivity (for the reasons mentioned above) may be useful in early detection of cases or even asymptomatic carriers, and the presence of other coexisting COVID-19-related symptoms (e.g., fever, dry cough) during smell testing time can support the test positive result; then, the diagnosis can be confirmed in positively tested subjects by viral detection methods.

\section{Major pathologies and features of anosmia}

Many agents and various pathologies can cause anosmia such as COVID-19, Parkinson's disease, Alzheimer's disease, rhinosinusitis (influenza \& allergic rhinitis), drugs, normal aging, stroke, human immunodeficiency virus, head trauma, environmental exposure (smoking, air pollution), depression, and schizophrenia. In various pathological conditions, anosmia is a reliable early symptom. Viral infections, such as SARS-CoV-2 and influenza virus, are common causes of anosmia (Table 1).

\section{Anosmia caused by influenza and common cold viruses}

Upper respiratory tract infections (URTIs) are a major cause of anosmia (Kalogjera and Dzepina 2012). The permanent smell loss in adulthood is most commonly caused by URS viruses (influenza, colds) (Deems et al. 1991). Rhinoviruses (RVs) are the main cause of common colds (Blaas 2016). The sense of smell can be affected by the viruses through two mechanisms of action. The first mechanism, induced by RVs and other coronavirus infections except SARS-CoV-2, is inducing inflammation in the nasal mucosa coating nasal passages. The mucosa becomes swollen and coated with a covering of nasal discharge leading to nasal obstruction which causes anosmia by preventing the odorant molecules from reaching and binding to their targeting receptors or by reducing the airflow which reduces the number of odorant molecules entering the nasal cavity (Akerlund et al. 1995; Rebholz et al. 2020). The second mechanism includes the damaging of the olfactory epithelium and its included nerves and cells (Welge-Lüssen and Wolfensberger 2006).

Anosmia after flu infection is possible as with other viruses (Suzuki et al. 2007). Loss of olfactory and taste sensations has not been discussed within the clinical features of the flu in medical literature (Paules and Subbarao 2017; Cavallazzi and Ramirez 2018). In a retrospective and observational study conducted in NFC (Nord Franche-Comté) Hospital, including 70 patients with confirmed COVID-19 and 54 patients with influenza Type A and B, loss of smell and taste sense was confirmed in $17 \%$ and $20 \%$, respectively in the influenza group, while in the COVID-19 patients, the loss of smell and taste was recorded in 53\% and 49\%, respectively (Zayet et al. 2020). 


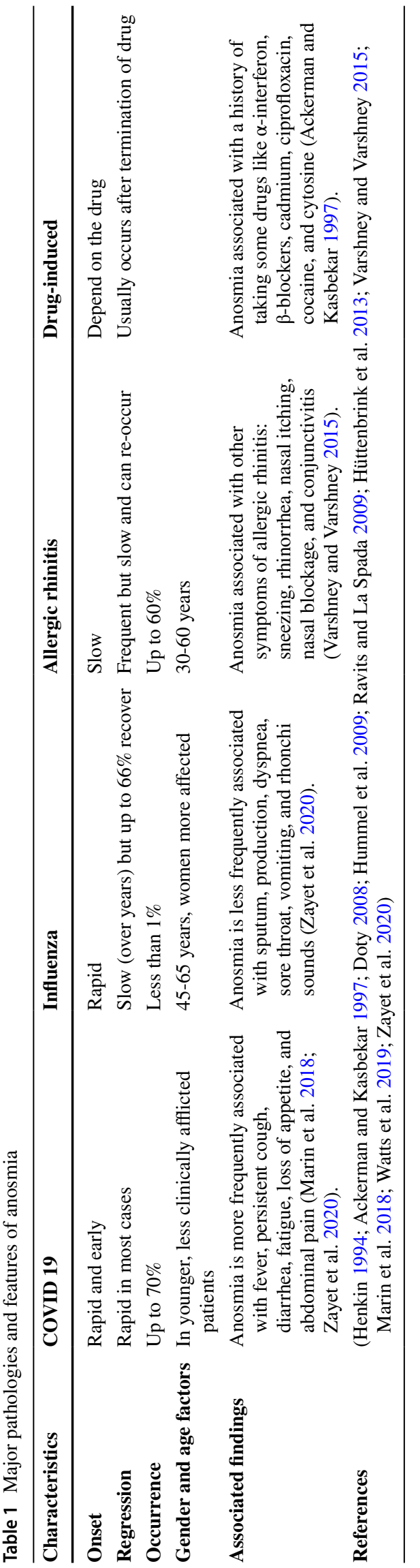

\section{Anosmia in allergic rhinitis}

Allergic rhinitis affects the nasal cavity because of the excessive inflammatory response of the immune system to several allergens present in the air such as bacteria, viruses, mold, dust, and pollen. The symptoms of allergic rhinitis are developed due to damage of the olfactory mucosa including sneezing, rhinorrhea, nasal itching, nasal blockage, and conjunctivitis, and loss of sense of smell and taste (Rebholz et al. 2020). Anosmia is also associated with allergic rhinitis (Imamura and Hasegawa-Ishii 2016; Rebholz et al. 2020). In the case of rhinitis/sinusitis, the interruption of airflow loaded with molecular particles to olfactory sensory neurons due to nasal obstruction is the main cause of loss of olfactory sense, but damage to the olfactory mucosa is also one of the possible causes (Imamura and Hasegawa-Ishii 2016).

\section{Drug-induced anosmia}

Among COVID-19 patients, about 13\% of the cases of anosmia are reported to be induced by drugs (Tuccori, Lapi et al. 2011). Many drugs impair the smell function (Ackerman and Kasbekar 1997; Fernández Fernández et al. 2000; Kraus and Vitezic 2000; Manzano Alonso et al. 2001; Chen et al. 2002; Kharoubi 2003; Ferraro et al. 2019) (Table 2). Smell disorders associated with drugs have two possible; direct and indirect. The direct mechanism includes a disturbance in both neurotransmitter function and neural interaction in sensory coding brain areas. The indirect mechanism includes modifications to the chemical environment of the sensing receptor, as well as physical barriers that prevent chemical molecules from reaching receptors (Doty and Bromley 2004). The macrolide azithromycin, used as a part of the treatment plan, is known to cause several chemosensory side effects including anosmia and parosmia (Ferraro et al. 2019). Also, drugs used for the treatment of hypertension (such as ACEIs and ARBs) and DM (such as thiazolidinedione) which are major comorbidities of COVID-19 infection are believed to cause upregulation of ACE2 receptors in both olfactory and oral mucosa which may worsen anosmia caused by COVID-19 infection (Fang et al. 2020).

\section{Management and treatment options of COVID-19 anosmia}

Corticosteroids are used to treat edema and inflammation associated with COVID-19 anosmia. However, the French Society of Otolaryngology recommends that corticosteroids should not be used in the treatment of SARS-CoV-2 anosmia (Russell et al. 2020). Therefore, precautions should be taken when using steroids in such situations to avoid complications associated with this therapy such as immunosuppression. 
Table 2 Drugs cause anosmia

\begin{tabular}{ll}
\hline Family & Members \\
\hline $\begin{array}{l}\text { Angiotensin-converting } \\
\text { enzyme inhibitors }\end{array}$ & Captopril, Enalapril. \\
$\begin{array}{l}\text { Anti-hypertensive } \\
\text { Antibiotic agents }\end{array}$ & Diltiazem, Nifedipine, Amlodipine, Felodipine, Candesartan. \\
CNS drugs & Azithromycin, Amikacin, Doxycycline, Ciprofloxacin, Cocaine, Cytosine, arabinoside. \\
Anti-cancer & Levodopa, Phenytoin, Tricyclic antidepressants, Amitriptyline, Imipramine, Lithium, Nortriptyline, Clozapine. \\
Anti-diabetic drugs & Cisplatin, Methotrexate, Vincristine. \\
Others & Glipizide, Insulin, Metformin, Levothyroxine. \\
& Auranofin, Colchicine, Gold, Methimazole, Corticosteroids (nasal), Propylthiouracil, $\beta$-Blockers, Fluvastatin, \\
& Interferon- $\alpha$, Lovastatin, Midodrine, Pegylated, Diuretics, interferon, Terbinafine, Xylocaine (nasal), \\
\hline
\end{tabular}

Using steroids intranasally is helpful in reducing the exacerbation of viral infection in the upper respiratory tract, olfactory dysfunction, and epithelial damage with less complication (Stenner et al. 2008; Jung and Kim 2020). Another strategy of the therapy is the administration of nasal saline irrigations containing drugs that act by competitive inhibition of ACE2 receptor (Wong et al. 2004), followed by nasal and oral corticosteroids (Lechien et al. 2020a, b, c).

ENT UK published a guide for the management of the loss of smell associated with COVID-19. They recommend considering referral when the symptoms of smell loss last more than 4-6 weeks in negative patients and do not have any other cause identified, or more than 3 months in COVID19 patients. In addition, the UK guidance recommended all patients with anosmia for more than 6 weeks with additional neurological symptoms regardless of COVID status to undergo MRI imaging of the brain (Walker et al. 2020) (Fig. 2). Patients are advised to follow the first-line treatment measures, which is the use of topical corticosteroid sprays and smell training until the specialist visits. There is a simple available method for the recovery of anosmia, which is smell training (Hummel et al. 2009; Damm et al. 2014; Pekala et al. 2016; Hummel et al. 2018; Kattar et al. 2021). The exposure to odours frequently for a prolonged time reduces the threshold to these odours and produces a sensitizing effect (Miwa et al. 2019).

Using theophylline to inhibit phosphodiesterase activity is a general approach for the improvement of the olfactory sensitivity by prolonging the intracellular signalling cascade which increases odor perception; however, this pharmacological choice is not effective in most cases (Gudziol and Hummel 2009). Therefore, several doctors suggested that the surgical intervention could be a solution to anosmia. However, it remains difficult to predict the extent of improvement in the olfactory function after the operation (Scangas and Bleier 2017). Coffee can affect the sense of smell in COVID19 patients, because of its caffeine content. It improves the cases but the recovery rates depend on if the cases have

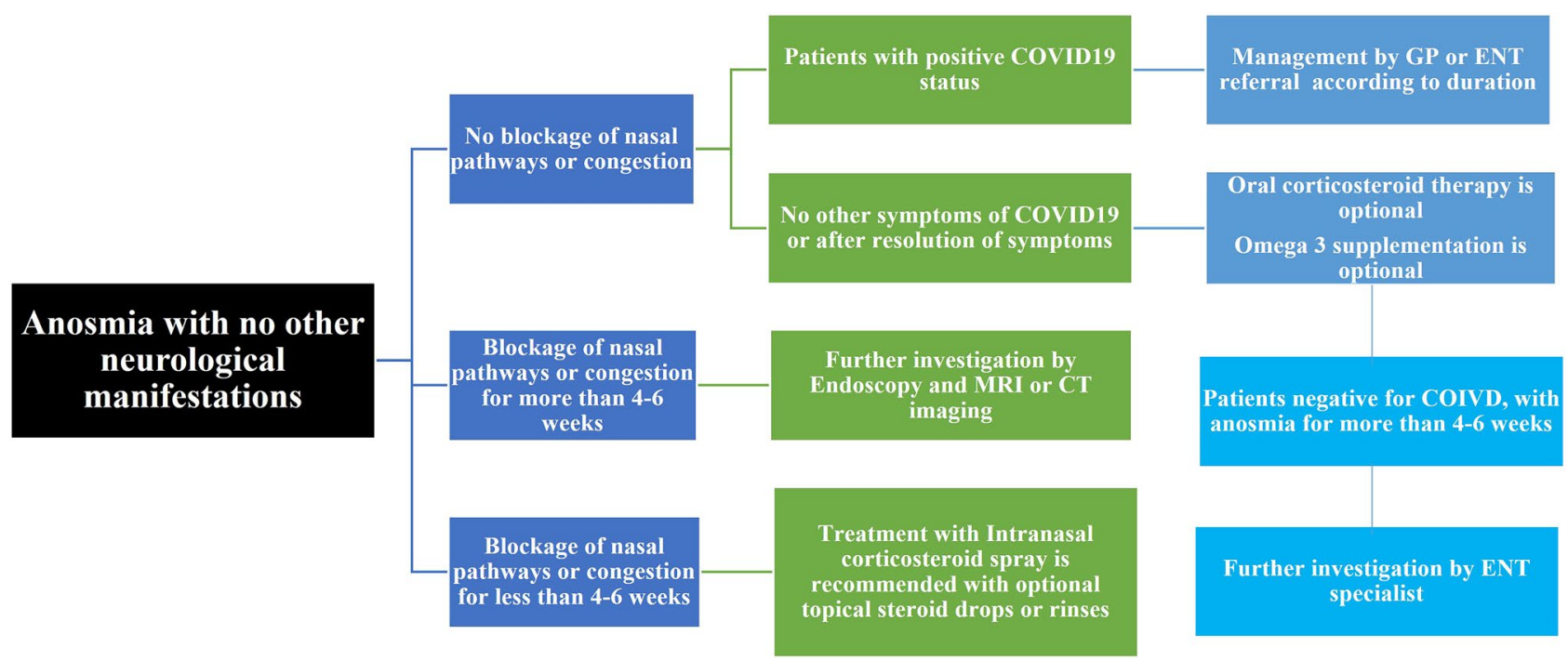

Fig. 2 Flow chart for management and treatment options of COVID-19 anosmia (adapted from Walker et al. 2020) 
any chronic disease such as hypertension, diabetes, or heart diseases-or not (Asiyeh et al. 2021). The recovery rate in cases without any chronic disease was higher than in cases with chronic diseases (Asiyeh et al. 2021).

\section{Evaluation of the smell function during COVID-19}

There is a large number of smell tests that have been developed, such as the Connecticut Chemosensory Clinical Research Center olfactory test (CCCRC), the University of Pennsylvania Smell Identification Test (UPSIT), and the Self-administered Computerized Olfactory Testing System (SCOTS) (Cain et al. 1983; Doty et al. 1984; Doty 2007; Jiang and Liang 2015). We are focusing here on the first two mentioned tests because they were applied to evaluate olfactory dysfunction in COVID-19 patients.

\section{The CCCRC test}

It measures the smell threshold and odor identification ability.

\section{The threshold measuring test}

$\mathrm{n}$-Butanol is used as the test substance. The highest concentration of this substance applied in this test is $4 \%$ and the concentrations are then decreased by 3 folds for each subsequent solution of n-butanol through the rest of the containers. Every container in the test has an opening that fits for one nostril. The subject is asked to sniff from an nbutanol container and a blank container (as a control) at each time to determine which container emits a stronger odor. The threshold is determined after 4 times of the correct answer at the same concentration. The average score of both nostrils represents the total score. Then, the composite score is determined; it ranges from 0 to 50, corresponding to the scores of the threshold test (Cain et al. 1983; Vaira et al. 2020a, b).

\section{The odor identification test}

It is composed of ten familiar odorants and ten distractors. The odorants are presented to each nostril, one at a time. The subject is asked to choose the correct odorant after smelling it. If the subject claims inability to smell an item, he/she does not have to identify it. The score scale of the odor identification (ID) test is from 1 to 10 , and the composite score scale is from 0 to 50 . The overall composite score (olfactory threshold composite score + odor identification composite score) is then calculated and compared to normative values (Cain et al. 1983; Vaira et al. 2020a, b).
Table 3 The standard cut-off points of the total scores of UPSIT and CCCRC test

\begin{tabular}{lcl}
\hline The degrees of the smell function & $\begin{array}{l}\text { UPSIT } \\
\text { score range }\end{array}$ & $\begin{array}{l}\text { CCCRC overall } \\
\text { composite score } \\
\text { range }\end{array}$ \\
\hline Normosmia & $31-40$ & $90-100$ \\
Mild hyposmia & $28-30$ & $70-80$ \\
Moderate hyposmia & $24-27$ & $50-60$ \\
Severe hyposmia & $17-23$ & $20-40$ \\
Anosmia & $6-16$ & $0-10$ \\
Probable malingering & $0-5$ & Undetectable \\
\hline
\end{tabular}

Despite the elegant approach, the test has some disadvantages (e.g., no standardization of odorants of the identification test, inability to detect malingerers, and the test duration is relatively long (about $35 \mathrm{~min}$ )) (Doty 2007).

\section{The UPSIT (the 40-odorant identification test)}

This test is present in the form of 4 ten-page booklets, every page contains a "scratch and sniff" strip embedded with a specific microencapsulated odorant and a multiple-choice question about it. The odor can be sniffed by one or both nostrils at a time. After sniffing the odorant, the patient selects a choice related to the odor out of four alternatives per question even if the odor is not perceived. After determining the total score of the test (according to the total number of the correct answers), the score is compared with standard database scores to estimate the degree of the patient's smell function (Doty et al. 1984; Doty 2007). This test is not a time-consumer (it takes about 10 to15 min). Table 3 shows the standard cut-off points of the total scores of UPSIT and CCCRC test (Moein et al. 2020; Vaira et al. 2020a, b).

\section{Conclusion}

The prevalence of anosmia is high among COVID-19 patients and may affect the quality of their life. Anosmia associated with COVID-19 can be the only diseasepresenting symptom that puts ENT doctors in the first line of COVID-19 contact. Therefore, anosmia must be considered by health workers an indication of suspicion for empirical diagnosis of COVID-19 infection. ENT specialists recommend several approaches for treatment of COVID-19 associated anosmia including pharmacological, surgical and smell training approaches.

Acknowledgement Figure 1 is created with Biorender.com.

Author contribution Data collection and literature search: Abdulrahman K. Ahmed, Reem Sayad, Islam A. Mahmoud, Aya M. Abd EL-Monem, 
Salma H. Badry, Islam H. Ibrahim. Writing the manuscript: Abdulrahman K. Ahmed, Reem Sayad, Islam A. Mahmoud, Aya M. Abd EL-Monem, Salma H. Badry, Islam H. Ibrahim, Mohamed A. El-Mokhtar, Ibrahim M. Sayed. Editing and revising the manuscript: Mohamed A. ElMokhtar and Ibrahim M. Sayed. Supervision: Mohamed A. El-Mokhtar and Ibrahim M. Sayed.

\section{Declarations}

Conflict of interest The authors declare no competing interests.

\section{References}

Abalo-Lojo JM, Pouso-Diz JM, Gonzalez F (2020) Taste and smell dysfunction in COVID-19 patients. Ann Otol Rhinol Laryngol 129(10):1041-1042

Ackerman BH, Kasbekar N (1997) Disturbances of taste and smell induced by drugs. Pharmacotherapy 17(3):482-496

Aggarwal S, Garcia-Telles N, Aggarwal G, Lavie C, Lippi G, Henry BM (2020) Clinical features, laboratory characteristics, and outcomes of patients hospitalized with coronavirus disease 2019 (COVID-19): Early report from the United States. Diagnosis (Berl) 7(2):91-96

Akerlund A, Bende M, Murphy C (1995) Olfactory threshold and nasal mucosal changes in experimentally induced common cold. Acta Otolaryngol 115(1):88-92

Altundag A, Saatci O, Sanli DET, Duz OA, Sanli AN, Olmuscelik O, Temirbekov D, Kandemirli SG, Karaaltin AB (2021) The temporal course of COVID-19 anosmia and relation to other clinical symptoms. Eur Arch Otorhinolaryngol 278(6):1891-1897

Andreini C, Banci L, Bertini I, Rosato A (2006) Counting the zincproteins encoded in the human genome. J Proteome Res 5(1):196-201

Aqrabawi AJ, Kim JC (2020) Olfactory memory representations are stored in the anterior olfactory nucleus. Nat Commun 11(1):1246

Asiyeh H, Esmaeil M, Mina Akbari M (2021) Research Square

Attems J, Walker L, Jellinger KA (2015) Olfaction and aging: a minireview. Gerontology 61(6):485-490

Beltrán-Corbellini Á, Chico-García JL, Martínez-Poles J, RodríguezJorge F, Natera-Villalba E, Gómez-Corral J, Gómez-López A, Monreal E, Parra-Díaz P, Cortés-Cuevas JL, Galán JC, FragolaArnau C, Porta-Etessam J, Masjuan J, Alonso-Cánovas A (2020) Acute-onset smell and taste disorders in the context of COVID19: a pilot multicentre polymerase chain reaction based casecontrol study. Eur J Neurol 27(9):1738-1741

Bilinska K, Jakubowska P, Von Bartheld CS, Butowt R (2020) Expression of the SARS-CoV-2 entry proteins, ACE2 and TMPRSS2, in cells of the olfactory epithelium: identification of cell types and trends with age. ACS Chem Neurosci 11(11):1555-1562

Bilinska K, von Bartheld CS, Butowt R (2021) Expression of the ACE2 virus entry protein in the nervus terminalis reveals the potential for an alternative route to brain infection in COVID-19. bioRxiv

Blaas D (2016) Viral entry pathways: the example of common cold viruses. Wien Med Wochenschr 166(7-8):211-226

Brann DH, Tsukahara T, Weinreb C, Lipovsek M, Van den Berge K, Gong B, Chance R, Macaulay IC, Chou HJ, Fletcher RB, Das D, Street K, de Bezieux HR, Choi YG, Risso D, Dudoit S, Purdom E, Mill J, Hachem RA, Matsunami H, Logan DW, Goldstein BJ, Grubb MS, Ngai J, Datta SR (2020) Non-neuronal expression of SARS-CoV-2 entry genes in the olfactory system suggests mechanisms underlying COVID-19-associated anosmia. Sci Adv 6(31)

Brann JH, Firestein SJ (2014) A lifetime of neurogenesis in the olfactory system. Front Neurosci 8:182
Brennan PA (2018) 50 years of decoding olfaction. Brain Neurosci Adv 2:2398212818817496

Bryche B, St Albin A, Murri S, Lacote S, Pulido C, Ar Gouilh M, Lesellier S, Servat A, Wasniewski M, Picard-Meyer E, Monchatre-Leroy E, Volmer R, Rampin O, Le Goffic R, Marianneau P, Meunier N (2020) Massive transient damage of the olfactory epithelium associated with infection of sustentacular cells by SARS-CoV-2 in golden Syrian hamsters. Brain Behav Immun 89:579-586

Bulfamante G, Chiumello D, Canevini MP, Priori A, Mazzanti M, Centanni S, Felisati G (2020) First ultrastructural autoptic findings of SARS -Cov-2 in olfactory pathways and brainstem. Minerva Anestesiol 86(6):678-679

Butowt R, Bilinska K (2020) SARS-CoV-2: Olfaction, brain infection, and the urgent need for clinical samples allowing earlier virus detection. ACS Chem Neurosci 11(9):1200-1203

Butowt R, Meunier N, Bryche B, von Bartheld CS (2021) The olfactory nerve is not a likely route to brain infection in COVID-19: a critical review of data from humans and animal models. Acta Neuropathol 141(6):809-822

Butowt R, von Bartheld CS (2021) Anosmia in COVID-19: underlying mechanisms and assessment of an olfactory route to brain infection. The Neuroscientist 27(6):582-603. https://doi.org/10. $1177 / 1073858420956905$

Cain WS, Gent J, Catalanotto FA, Goodspeed RB (1983) Clinical evaluation of olfaction. Am J Otolaryngol 4(4):252-256

Cavallazzi R, Ramirez JA (2018) Influenza and viral pneumonia. Clin Chest Med 39(4):703-721

Chen L, Zhao J, Peng J, Li X, Deng X, Geng Z, Shen Z, Guo F, Zhang Q, Jin Y, Wang L, Wang S (2020a) Detection of SARS-CoV-2 in saliva and characterization of oral symptoms in COVID-19 patients. Cell Prolif 53(12):e12923

Chen R, Wang K, Yu J, Howard D, French L, Chen Z, Wen C, Xu Z (2020b) The spatial and cell-type distribution of SARS-CoV-2 receptor ACE2 in the human and mouse brains. Front Neurol 11:573095

Chen RY, Desmond PV, Locarnini SA (2002) Emerging therapies of hepatitis B and C. J Gastroenterol Hepatol 17(Suppl):S471-481

Cooper KW, Brann DH, Farruggia MC, Bhutani S, Pellegrino R, Tsukahara T, Weinreb C, Joseph PV, Larson ED, Parma V, Albers MW, Barlow LA, Datta SR, Di Pizio A (2020) COVID-19 and the chemical senses: supporting players take center stage. Neuron 107(2):219-233

Damm M, Pikart LK, Reimann H, Burkert S, Göktas Ö, Haxel B, Frey S, Charalampakis I, Beule A, Renner B, Hummel T, Hüttenbrink KB (2014) Olfactory training is helpful in postinfectious olfactory loss: a randomized, controlled, multicenter study. Laryngoscope 124(4):826-831

Deems DA, Doty RL, Settle RG, Moore-Gillon V, Shaman P, Mester AF, Kimmelman CP, Brightman VJ, Snow JB Jr (1991) Smell and taste disorders, a study of 750 patients from the University of Pennsylvania Smell and Taste Center. Arch Otolaryngol Head Neck Surg 117(5):519-528

Diodato A, Ruinart de Brimont M, Yim YS, Derian N, Perrin S, Pouch J, Klatzmann D, Garel S, Choi GB, Fleischmann A (2016) Molecular signatures of neural connectivity in the olfactory cortex. Nat Commun 7:12238

Doty RL (2007) Office procedures for quantitative assessment of olfactory function. Am J Rhinol 21(4):460-473

Doty RL (2008) The olfactory vector hypothesis of neurodegenerative disease: is it viable?. Ann Neurol 63(1):7-15

Doty RL, Bromley SM (2004) Effects of drugs on olfaction and taste. Otolaryngol Clin North Am 37(6):1229-1254

Doty RL, Shaman P, Kimmelman CP, Dann MS (1984) University of Pennsylvania Smell Identification Test: a rapid quantitative olfactory function test for the clinic. Laryngoscope 94(2 Pt 1):176-178 
Eliezer M, Hamel AL, Houdart E, Herman P, Housset J, Jourdaine C, Eloit C, Verillaud B, Hautefort C (2020) Loss of smell in patients with COVID-19: MRI data reveal a transient edema of the olfactory clefts. Neurology 95(23):e3145-e3152

Fang L, Karakiulakis G, Roth M (2020) Are patients with hypertension and diabetes mellitus at increased risk for COVID-19 infection?. Lancet Respir Med 8(4):e21

Fernández Fernández FJ, Castiella Eguzkiza A, Tejada Calabia AM, García Bengoechea M (2000) Anosmia secondary to treatment with interferon in a patient with chronic hepatitis C. Gastroenterol Hepatol 23(10):499-500

Ferraro S, Convertino I, Leonardi L, Blandizzi C, Tuccori M (2019) Unresolved gustatory, olfactory and auditory adverse drug reactions to antibiotic drugs: a survey of spontaneous reporting to Eudravigilance. Expert Opin Drug Saf 18(12):1245-1253

Fukada T, Kambe T (2018) Welcome to the world of zinc signaling. Int J Mol Sci 19(3)

Gautier JF, Ravussin Y (2020) A new symptom of COVID-19: loss of taste and smell. Obesity (Silver Spring) 28(5):848

Gilani S, Roditi R, Naraghi M (2020) COVID-19 and anosmia in Tehran, Iran. Med Hypotheses 141:109757

Gomez-Pinedo U, Matias-Guiu J, Sanclemente-Alaman I, MorenoJimenez L, Montero-Escribano P, Matias-Guiu JA (2020) Is the brain a reservoir organ for SARS-CoV2? J Med Virol 92(11):2354-2355

Gudziol V, Hummel T (2009) Effects of pentoxifylline on olfactory sensitivity: a postmarketing surveillance study. Arch Otolaryngol Head Neck Surg 135(3):291-295

Hamming I, Timens W, Bulthuis ML, Lely AT, Navis G, van Goor H (2004) Tissue distribution of ACE2 protein, the functional receptor for SARS coronavirus. A first step in understanding SARS pathogenesis. J Pathol 203(2):631-637

Heidari F, Karimi E, Firouzifar M, Khamushian P, Ansari R, Mohammadi Ardehali M, Heidari F (2020) Anosmia as a prominent symptom of COVID-19 infection. Rhinology 58(3):302-303

Helms J, Kremer S, Merdji H, Schenck M, Severac F, Clere-Jehl R, Studer A, Radosavljevic M, Kummerlen C, Monnier A, Boulay C, Fafi-Kremer S, Castelain V, Ohana M, Anheim M, Schneider F, Meziani F (2020) Delirium and encephalopathy in severe COVID-19: a cohort analysis of ICU patients. Crit Care 24(1):491

Henkin RI (1994) Drug-induced taste and smell disorders. Incidence, mechanisms and management related primarily to treatment of sensory receptor dysfunction. Drug Saf 11(5):318-377

Heydel JM, Coelho A, Thiebaud N, Legendre A, Le Bon AM, Faure P, Neiers F, Artur Y, Golebiowski J, Briand L (2013) Odorantbinding proteins and xenobiotic metabolizing enzymes: implications in olfactory perireceptor events. Anat Rec (Hoboken) 296(9):1333-1345

Hopkins C, Surda P, Whitehead E, Kumar BN (2020) Early recovery following new onset anosmia during the COVID-19 pandemic - an observational cohort study. J Otolaryngol Head Neck Surg 49(1):26

Hornuss D, Lange B, Schröter N, Rieg S, Kern WV, Wagner D (2020) Anosmia in COVID-19 patients. Clin Microbiol Infect 26(10):1426-1427

Huang C, Wang Y, Li X, Ren L, Zhao J, Hu Y, Zhang L, Fan G, Xu J, Gu X, Cheng Z, Yu T, Xia J, Wei Y, Wu W, Xie X, Yin W, Li H, Liu M, Xiao Y, Gao H, Guo L, Xie J, Wang G, Jiang R, Gao Z, Jin Q, Wang J, Cao B (2020) Clinical features of patients infected with 2019 novel coronavirus in Wuhan, China. Lancet 395(10223):497-506

Huart C, Philpott C, Konstantinidis I, Altundag A, Whitcroft KL, Trecca EMC, Cassano M, Rombaux P, Hummel T (2020) Comparison of COVID-19 and common cold chemosensory dysfunction. Rhinology 58(6):623-625
Hummel T, Rissom K, Reden J, Hähner A, Weidenbecher M, Hüttenbrink KB (2009) Effects of olfactory training in patients with olfactory loss. Laryngoscope 119(3):496-499

Hummel T, Stupka G, Haehner A, Poletti SC (2018) Olfactory training changes electrophysiological responses at the level of the olfactory epithelium. Rhinology 56(4):330-335

Hüttenbrink KB, Hummel T, Berg D, Gasser T, Hähner A (2013) Olfactory dysfunction: common in later life and early warning of neurodegenerative disease. Dtsch Arztebl Int 110(1-2):1-7, e1

Imamura F, Hasegawa-Ishii S (2016) Environmental toxicants-induced immune responses in the olfactory mucosa. Front Immunol 7:475

Jiang RS, Liang KL (2015) A pilot study of the self-administered computerized olfactory testing system. Am J Rhinol Allergy 29(2): $555-58$

Jung AY, Kim YH (2020) Reversal of olfactory disturbance in allergic rhinitis related to OMP suppression by intranasal budesonide treatment. Allergy Asthma Immunol Res 12(1):110-124

Kalogjera L, Dzepina D (2012) Management of smell dysfunction. Curr Allergy Asthma Rep

Kandemirli SG, Altundag A, Yildirim D, Tekcan Sanli DE, Saatci O (2021) Olfactory bulb MRI and paranasal sinus CT findings in persistent COVID-19 anosmia. Acad Radiol 28(1):28-35

Kattar N, Do TM, Unis GD, Migneron MR, Thomas AJ, McCoul ED (2021) Olfactory training for postviral olfactory dysfunction: systematic review and meta-analysis. Otolaryngol Head Neck Surg 164(2):244-254

Kaye R, Chang CWD, Kazahaya K, Brereton J, Denneny JC 3rd (2020) COVID-19 anosmia reporting tool: initial findings. Otolaryngol Head Neck Surg 163(1):132-134

Kern RC (2000) Chronic sinusitis and anosmia: pathologic changes in the olfactory mucosa. Laryngoscope 110(7):1071-1077

Kharoubi S (2003) Drug induced anosmia with nifedipine. Presse Med 32(27):1269-1272

Komai M, Goto T, Suzuki H, Takeda T, Furukawa Y (2000) Zinc deficiency and taste dysfunction; contribution of carbonic anhydrase, a zinc-metalloenzyme, to normal taste sensation. Biofactors 12(1-4):65-70

Kraus I, Vitezic D (2000) Anosmia induced with alpha interferon in a patient with chronic hepatitis C. Int J Clin Pharmacol Ther 38(7):360-361

Lambrecq V, Hanin A, Munoz-Musat E, Chougar L, Gassama L, Delorme C, Cousyn L, Borden A, Damiano M, Frazzini V, Huberfeld G, Landgraf F, Nguyen-Michel VH, Pichit P, Sangare A, Chavez M, Morelot-Panzini C, Morawiec E, Raux M, Luyt CE, Rufat P, Galanaud D, Corvol JC, Lubetzki C, Rohaut B, Demeret S, Pyatigorskaya N, Naccache L, Navarro V, Cohort CNSG (2021) Association of clinical, biological, and brain magnetic resonance imaging findings with electroencephalographic findings for patients with COVID-19. JAMA Netw Open 4(3):e211489

Laurendon T, Radulesco T, Mugnier J, Gérault M, Chagnaud C, El Ahmadi AA, Varoquaux A (2020) Bilateral transient olfactory bulb edema during COVID-19-related anosmia. Neurology 95(5):224-225

Lechien JR, Chiesa-Estomba CM, De Siati DR, Horoi M, Le Bon SD, Rodriguez A, Dequanter D, Blecic S, El Afia F, Distinguin L, Chekkoury-Idrissi Y, Hans S, Delgado IL, Calvo-Henriquez C, Lavigne P, Falanga C, Barillari MR, Cammaroto G, Khalife M, Leich P, Souchay C, Rossi C, Journe F, Hsieh J, Edjlali M, Carlier R, Ris L, Lovato A, De Filippis C, Coppee F, Fakhry N, Ayad T, Saussez S (2020a) Olfactory and gustatory dysfunctions as a clinical presentation of mild-to-moderate forms of the coronavirus disease (COVID-19): a multicenter European study. Eur Arch Otorhinolaryngol 277(8):2251-2261

Lechien JR, Chiesa-Estomba CM, Hans S, Barillari MR, Jouffe L, Saussez S (2020b) Loss of smell and taste in 2013 European 
patients with mild to moderate COVID-19. Ann Intern Med 173(8):672-675

Lechien JR, Chiesa-Estomba CM, Place S, Van Laethem Y, Cabaraux P, Mat Q, Huet K, Plzak J, Horoi M, Hans S, Rosaria Barillari M, Cammaroto G, Fakhry N, Martiny D, Ayad T, Jouffe L, Hopkins C, Saussez S (2020c) Clinical and epidemiological characteristics of 1420 European patients with mild-to-moderate coronavirus disease 2019. J Intern Med 288(3):335-344

Li SR, Tang ZJ, Li ZH, Liu X (2020a) Searching therapeutic strategy of new coronavirus pneumonia from angiotensin-converting enzyme 2: the target of COVID-19 and SARS-CoV. Eur J Clin Microbiol Infect Dis 39(6):1021-1026

Li YC, Bai WZ, Hashikawa T (2020b) The neuroinvasive potential of SARS-CoV2 may play a role in the respiratory failure of COVID-19 patients. J Med Virol 92(6):552-555

Liang F (2018) Olfactory receptor neuronal dendrites become mostly intrasustentacularly enwrapped upon maturity. J Anat 232(4):674-685

Manzano Alonso ML, Muñoz Gómez R, Castellano Tortajada G, Solis Herruzo JA (2001) IFN-induced anosmia y ageusia in chronic hepatitis C. Gastroenterol Hepatol 24(8):412

Marin C, Vilas D, Langdon C, Alobid I, López-Chacón M, Haehner A, Hummel T, Mullol J (2018) Olfactory dysfunction in neurodegenerative diseases. Curr Allergy Asthma Rep 18(8):42

Matschke J, Lutgehetmann M, Hagel C, Sperhake JP, Schroder AS, Edler C, Mushumba H, Fitzek A, Allweiss L, Dandri M, Dottermusch M, Heinemann A, Pfefferle S, Schwabenland M, Sumner Magruder D, Bonn S, Prinz M, Gerloff C, Puschel K, Krasemann S, Aepfelbacher M, Glatzel M (2020) Neuropathology of patients with COVID-19 in Germany: a post-mortem case series. Lancet Neurol 19(11):919-929

Meinhardt J, Radke J, Dittmayer C, Franz J, Thomas C, Mothes R, Laue M, Schneider J, Brünink S, Greuel S, Lehmann M, Hassan O, Aschman T, Schumann E, Chua RL, Conrad C, Eils R, Stenzel W, Windgassen M, Rößler L, Goebel HH, Gelderblom HR, Martin H, Nitsche A, Schulz-Schaeffer WJ, Hakroush S, Winkler MS, Tampe B, Scheibe F, Körtvélyessy P, Reinhold D, Siegmund B, Kühl AA, Elezkurtaj S, Horst D, Oesterhelweg L, Tsokos M, Ingold-Heppner B, Stadelmann C, Drosten C, Corman VM, Radbruch H, Heppner FL (2021) Olfactory transmucosal SARS-CoV-2 invasion as a port of central nervous system entry in individuals with COVID-19. Nat Neurosci 24(2):168-175

Merza MA, Haleem Al Mezori AA, Mohammed HM, Abdulah DM (2020) COVID-19 outbreak in Iraqi Kurdistan: the first report characterizing epidemiological, clinical, laboratory, and radiological findings of the disease. Diabetes Metab Syndr 14(4):547-554

Miwa T, Ikeda K, Ishibashi T, Kobayashi M, Kondo K, Matsuwaki Y, Ogawa T, Shiga H, Suzuki M, Tsuzuki K, Furuta A, Motoo Y, Fujieda S, Kurono Y (2019) Clinical practice guidelines for the management of olfactory dysfunction - secondary publication. Auris Nasus Larynx 46(5):653-662

Moein ST, Hashemian SM, Mansourafshar B, Khorram-Tousi A, Tabarsi P, Doty RL (2020) Smell dysfunction: a biomarker for COVID-19. Int Forum Allergy Rhinol 10(8):944-950

Netland J, Meyerholz DK, Moore S, Cassell M, Perlman S (2008) Severe acute respiratory syndrome coronavirus infection causes neuronal death in the absence of encephalitis in mice transgenic for human ACE2. J Virol 82(15):7264-7275

Paniz-Mondolfi A, Bryce C, Grimes Z, Gordon RE, Reidy J, Lednicky J, Sordillo EM, Fowkes M (2020) Central nervous system involvement by severe acute respiratory syndrome coronavirus-2 (SARSCoV-2). J Med Virol 92(7):699-702

Paules C, Subbarao K (2017) Influenza. Lancet 390(10095):697-708

Pekala K, Chandra RK, Turner JH (2016) Efficacy of olfactory training in patients with olfactory loss: a systematic review and metaanalysis. Int Forum Allergy Rhinol 6(3):299-307
Politi LS, Salsano E, Grimaldi M (2020) Magnetic resonance imaging alteration of the brain in a patient with coronavirus disease 2019 (COVID-19) and anosmia. JAMA Neurol 77(8):1028-1029

Ravits JM, La Spada AR (2009) ALS motor phenotype heterogeneity, focality, and spread: deconstructing motor neuron degeneration. Neurology 73(10):805-811

Rebholz H, Braun RJ, Ladage D, Knoll W, Kleber C, Hassel AW (2020) Loss of olfactory function-early indicator for Covid-19, other viral infections and neurodegenerative disorders. Front Neurol 11:569333

Roland LT, Gurrola JG 2nd, Loftus PA, Cheung SW, Chang JL (2020) Smell and taste symptom-based predictive model for COVID-19 diagnosis. Int Forum Allergy Rhinol 10(7):832-838

Russell B, Moss C, Rigg A, Van Hemelrijck M (2020) COVID-19 and treatment with NSAIDs and corticosteroids: should we be limiting their use in the clinical setting? Ecancermedicalscience $14: 1023$

Salmon Ceron D, Bartier S, Hautefort C, Nguyen Y, Nevoux J, Hamel AL, Camhi Y, Canouï-Poitrine F, Verillaud B, Slama D, HaimBoukobza S, Sourdeau E, Cantin D, Corré A, Bryn A, Etienne N, Rozenberg F, Layese R, Papon JF, Bequignon E (2020) Selfreported loss of smell without nasal obstruction to identify COVID-19. The multicenter Coranosmia cohort study. J Infect 81(4):614-620

Scangas GA, Bleier BS (2017) Anosmia: differential diagnosis, evaluation, and management. Am J Rhinol Allergy 31(1):3-7

Schwob JE (2002) Neural regeneration and the peripheral olfactory system. Anat Rec 269(1):33-49

Schwob JE, Youngentob SL, Mezza RC (1995) Reconstitution of the rat olfactory epithelium after methyl bromide-induced lesion. J Comp Neurol 359(1):15-37

Shankar AH, Prasad AS (1998) Zinc and immune function: the biological basis of altered resistance to infection. Am J Clin Nutr 68(2 Suppl):447s-463s

Srinivas U, Braconier JH, Jeppsson B, Abdulla M, Akesson B, Ockerman PA (1988) Trace element alterations in infectious diseases. Scand J Clin Lab Invest 48(6):495-500

Stenner M, Vent J, Hüttenbrink KB, Hummel T, Damm M (2008) Topical therapy in anosmia: relevance of steroid-responsiveness. Laryngoscope 118(9):1681-1686

Sungnak W, Huang N, Bécavin C, Berg M, Queen R, Litvinukova M, Talavera-López C, Maatz H, Reichart D, Sampaziotis F, Worlock KB, Yoshida M, Barnes JL (2020) SARS-CoV-2 entry factors are highly expressed in nasal epithelial cells together with innate immune genes. Nat Med 26(5):681-687

Suzuki M, Saito K, Min WP, Vladau C, Toida K, Itoh H, Murakami S (2007) Identification of viruses in patients with postviral olfactory dysfunction. Laryngoscope 117(2):272-277

Trotier D, Bensimon JL, Herman P, P. Tran Ba Huy, K. B. Døving and C. Eloit, (2007) Inflammatory obstruction of the olfactory clefts and olfactory loss in humans: a new syndrome? Chem Senses 32(3):285-292

Tsivgoulis G, Fragkou PC, Lachanis S, Palaiodimou L, Lambadiari V, Papathanasiou M, Sfikakis PP, Voumvourakis KI, Tsiodras S (2021) Olfactory bulb and mucosa abnormalities in persistent COVID-19-induced anosmia: a magnetic resonance imaging study. Eur J Neurol 28(1):e6-e8

Tuccori M, Lapi F, Testi A, Ruggiero E, Moretti U, Vannacci A, Bonaiuti R, Antonioli L, Fornai M, Giustarini G, Scollo C, Corona T, Ferrazin F, Sottosanti L, Blandizzi C (2011) Drug-induced taste and smell alterations: a case/non-case evaluation of an italian database of spontaneous adverse drug reaction reporting. Drug Saf 34(10):849-859

Vaira LA, Deiana G, Fois AG, Pirina P, Madeddu G, De Vito A, Babudieri S, Petrocelli M, Serra A, Bussu F, Ligas E, Salzano G, De Riu G (2020a) 
Objective evaluation of anosmia and ageusia in COVID-19 patients: single-center experience on 72 cases. Head Neck 42(6):1252-1258

Vaira LA, Salzano G, Deiana G, De Riu G (2020b) Anosmia and ageusia: common findings in COVID-19 patients. Laryngoscope 130(7): 1787

van Riel D, Verdijk R, Kuiken T (2015) The olfactory nerve: a shortcut for influenza and other viral diseases into the central nervous system. J Pathol 235(2):277-287

Varshney J, Varshney H (2015) Allergic rhinitis: an overview. Indian J Otolaryngol Head Neck Surg 67(2):143-149

von Bartheld CS, Hagen MM, Butowt R (2020) Prevalence of chemosensory dysfunction in COVID-19 patients: a systematic review and meta-analysis reveals significant ethnic differences. ACS Chem Neurosci 11(19):2944-2961

Walker A, Pottinger G, Scott A, Hopkins C (2020) Anosmia and loss of smell in the era of covid-19. BMJ 370:m2808

Watts AM, Cripps AW, West NP, Cox AJ (2019) Modulation of allergic inflammation in the nasal mucosa of allergic rhinitis sufferers with topical pharmaceutical agents. Front Pharmacol 10:294

Welge-Lüssen A, Wolfensberger M (2006) Olfactory disorders following upper respiratory tract infections. Adv Otorhinolaryngol 63:125-132

Wessels I, Rolles B, Rink L (2020) The potential impact of zinc supplementation on COVID-19 pathogenesis. Front Immunol 11:1712
Wong SK, Li W, Moore MJ, Choe H, Farzan M (2004) A $193-$ amino acid fragment of the SARS coronavirus $S$ protein efficiently binds angiotensin-converting enzyme 2 . J Biol Chem 279(5):3197-3201

Yan CH, Faraji F, Prajapati DP, Ostrander BT, DeConde AS (2020) Self-reported olfactory loss associates with outpatient clinical course in COVID-19. Int Forum Allergy Rhinol 10(7):821-831

Zayet S, Kadiane-Oussou NJ, Lepiller Q, Zahra H, Royer PY, Toko L, Gendrin V, Klopfenstein T (2020) Clinical features of COVID19 and influenza: a comparative study on Nord Franche-Comte cluster. Microbes Infect 22(9):481-488

Zhang L, Zhou L, Bao L, Liu J, Zhu H, Lv Q, Liu R, Chen W, Tong W, Wei Q, Xu Y, Deng W, Gao H, Xue J, Song Z, Yu P, Han Y, Zhang Y, Sun X, Yu X, Qin C (2021) SARS-CoV-2 crosses the blood-brain barrier accompanied with basement membrane disruption without tight junctions alteration. Signal Transduction and Targeted Therapy 6(1):337

Zhu N, Zhang D, Wang W, Li X, Yang B, Song J, Zhao X, Huang B, Shi W, Lu R, Niu P, Zhan F, Ma X, Wang D, Xu W, Wu G, Gao GF, Tan W (2020) A novel coronavirus from patients with pneumonia in China, 2019. N Engl J Med 382(8):727-733

Publisher's Note Springer Nature remains neutral with regard to jurisdictional claims in published maps and institutional affiliations. 